\title{
Retraction Note: Long noncoding RNA MLK7-AS1 promotes ovarian cancer cells progression by modulating miR-375/YAP1 axis
}

Huan Yan ${ }^{1,2}$, Hong Li ${ }^{1}$, Pengyun $\mathrm{Li}^{3}$, Xia Li ${ }^{1}$, Jianjian Lin ${ }^{4}$, Linlin Zhu ${ }^{5}$, Maria A. Silva ${ }^{2}$, Xiaofang Wang ${ }^{6}$, Ping Wang $^{3}$ and Zhan Zhang ${ }^{1,3^{*}}$

\section{Retraction Note: J Exp Clin Cancer Res 37, 237 (2018) https://doi.org/10.1186/s13046-018-0910-4}

This article [1] was retracted at the request of the corresponding author. After its publication it transpired that incorrect images have been used in Figure 8A and $8 \mathrm{~B}$. The authors have been unable to replace these images. The conclusions of the paper are therefore unreliable.

\section{Author details}

'Department of Obstetrics and Gynecology, The Third Affiliated Hospital of Zhengzhou University, Zhengzhou, Henan, People's Republic of China.

${ }^{2}$ Department of Pathology and Laboratory Medicine, University of Tennessee Health Science Center, Memphis, TN, USA. ${ }^{3}$ Department of Clinical

Laboratory, The Third Affiliated Hospital of Zhengzhou University, No. 7 Front Kangfu Street, Zhengzhou 450052, Henan, People's Republic of China.

${ }^{4}$ Department of Bioscience, University of Tennessee Health Science Center, Memphis, TN, USA. ${ }^{5}$ Collaborative Innovation Center of Molecular Diagnosis and Laboratory Medicine, Xinxiang Medical University, Xinxiang, Henan, People's Republic of China. ${ }^{6}$ Department of Reproductive Medicine Center, The People's Hospital of Henan Province, Zhengzhou, Henan, People's Republic of China.
Published online: 05 November 2020

\section{Reference}

1. Yan H, Li H, Li P, et al. Long noncoding RNA MLKT-AS1 promotes ovarian cancer cells progression by modulating miR-375/YAP1 axis. J Exp Clin Cancer Res. 2018;37:237. https://doi.org/10.1186/s13046-018-0910-4.

The original article can be found online at https://doi.org/10.1186/s13046018-0910-4.

* Correspondence: zhangzhanxm@163.com

'Department of Obstetrics and Gynecology, The Third Affiliated Hospital of

Zhengzhou University, Zhengzhou, Henan, People's Republic of China

${ }^{3}$ Department of Clinical Laboratory, The Third Affiliated Hospital of

Zhengzhou University, No. 7 Front Kangfu Street, Zhengzhou 450052, Henan, People's Republic of China

Full list of author information is available at the end of the article

\section{$\triangle B M C$}

(c) The Author(s). 2020 Open Access This article is licensed under a Creative Commons Attribution 4.0 International License, which permits use, sharing, adaptation, distribution and reproduction in any medium or format, as long as you give appropriate credit to the original author(s) and the source, provide a link to the Creative Commons licence, and indicate if changes were made. The images or other third party material in this article are included in the article's Creative Commons licence, unless indicated otherwise in a credit line to the material. If material is not included in the article's Creative Commons licence and your intended use is not permitted by statutory regulation or exceeds the permitted use, you will need to obtain permission directly from the copyright holder. To view a copy of this licence, visit http://creativecommons.org/licenses/by/4.0/ The Creative Commons Public Domain Dedication waiver (http://creativecommons.org/publicdomain/zero/1.0/) applies to the data made available in this article, unless otherwise stated in a credit line to the data. 